\title{
Client Relationship Management in Latvian Retail Enterprises Under COVID-19 Circumstances
}

\author{
Iveta Linina \\ Turiba University, Latvia \\ Iveta.linina@turiba.lv
}

\author{
Rosita Zvirgzdina \\ Turiba University, Latvia \\ rosita@turiba.lv
}

\author{
Velga Vevere \\ EKA University College of Applied \\ Sciences, Latvia \\ velga.vevere@gmail.com
}

\begin{abstract}
Ensuring customer satisfaction is the key to a successful retail business. The process of attracting new customers always involves more money, time and energy. In order for a company to retain existing customers and build relationships with them, one of the basic tasks is to know the factors and levels that affect their satisfaction. In the current situation of COVI-19, this poses even greater obstacles and challenges. In order to identify the company's ability to ensure competitiveness in a crisis situation, the authors have set the goal of the research to study the factors influencing retail consumer behavior under COVID-19 circumstances.
\end{abstract}

This study will provide retail businesses with an understanding of the need for consumer relationship management in a restricted situation. From the scientific point of view, the authors have analyzed the theoretical aspects and summarized the approach to the understanding of buyers' behavior in crisis conditions. As a result of the research, the authors conclude that even in crisis situations, companies can manage the relationship with consumers and shape the attitude of buyers, which can be one of the tools for ensuring competitiveness.

Keywords - consumer; consumer satisfaction; consumer relationship management; retail trade

\section{INTODUCTION}

The Covid 19 pandemic is also affecting retail businesses, forcing them to look for solutions to ensure and develop competitiveness. A retail company's focus on customer satisfaction and loyalty is one way to become competitive. This is especially true in the current context of the Covid 19 pandemic, when consumer dissatisfaction with government decisions and restrictions is growing. Building customer satisfaction and loyalty is based on purposeful relationship building. This goal must be based on creating a competitive and sustainable development of a trading company. Latvian retail companies do not have sufficient understanding of consumer relationship management and its benefits. The study examines the level of management development and use of Latvian retail companies' relationships with customers. Gaining an understanding of the target audience and developing marketing activities and communication based on this understanding increases customer satisfaction and builds loyalty, which in turn can ensure and increase competitiveness. In order to identify factors for building and ensuring customer relationship management in retail, the authors of the study have set the goal of the research to study the factors influencing retail consumer behavior under COVID-19 circumstances. In order to achieve the goal, the following tasks were set:

1. To analyze information on the principles of customer satisfaction and loyalty management.

2. To describe the Latvian retail sector and its operation in the conditions of the Covid 19 pandemic.

3. To determine the basic factors of building customer satisfaction and loyalty and their successful application in Latvian retail companies in the conditions of the Covid 19 pandemic.

In order to determine the basic factors of customer satisfaction and loyalty in Latvia in the conditions of the Covid 19 pandemic and their use in building and managing customer relationships in retail companies in Latvia, a customer survey was conducted. As a result of the research, proposals were made for building customer satisfaction and loyalty. The following limitations were set in the course of the study: the problem is studied mainly from the methodological aspects and the age and income level of the respondents to the survey were not taken into account. Research period: November 1, 2020 to March 1, 2021. The following research methods were used in the research: logical-constructive method - for comparison of theoretical material with empirical results; graphical - for display and analysis of visually collected information and consumer 
survey. The methodological basis of the research is foreign works and publications (P. DePelsmacker, J. Eskildsen, K. Kriestensen, M. Krauss, D. O` Reilijs, D. Gibass, etc.) process.

\section{RESULTS AND DISCUSSION}

Many specialists, researchers and managers today have come to the conclusion that in the conditions of fierce competition, one of the most important factors for the success of companies is consumer satisfaction with the offers and their loyalty to the product / brand / company. It is a favorable attitude and loyalty that is the basis for building a company's consumer capital. However, in order to achieve the desired level of consumer satisfaction and loyalty, the company must lead the process of relationship with consumers.

Analyzing several publications and other sources in the field of consumer relationship management (Reisheld, 2003; Evans, 2012; Butscger \& Stephan, 2002; Kotler \& Keller, 2006, 196-197; Toedt, 2015; Harker, 1999; etc.), the author is has come to the conclusion that four systems studied in theory and used in practice should be highlighted in retail:

1) Loyalty Program - LP;

2) Consumer Relationship Management - CRM;

3) Efficient Consumer Response - ECR;

4) Relationship Marketing Management - RMM.

Retail companies use different management systems in practice, but as they evolve, each new system incorporates both positive and proven elements from the previous system and new elements. This process is illustrated in 1.1. in the picture.

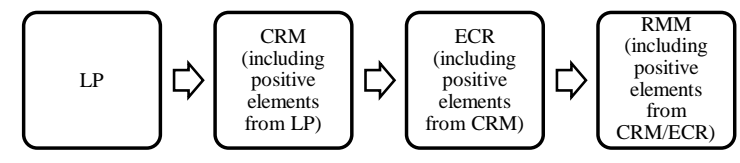

Fig. 1. Evolution of consumer relationship management systems in retail Linina, 2017).

The authors analyzed the literature on each of the management systems mentioned in Figure 1 and the experience of their practical use in order to draw conclusions about their differences, common elements, advantages and disadvantages.

Loyalty programs are used by many companies on all continents of the world.

F. Reisheld believes that the consumer loyalty program is aimed at increasing consumer activity through a systematic impact on consumer behavior (Reisheld, 2003).

M. Evans believes that the essence of the consumer loyalty program is the support and rewarding of the consumer for his constant cooperation with the company and making purchases (Evans, 2012). According to S. Butscher and A. Stephan, a company organizes a loyalty program with the aim of constant direct communication, creating an emotional connection with consumers and offering them a set of benefits with greater added value to increase the level of loyalty (Butscger \& Stephan, 2002). A loyalty program can be defined as a set of marketing activities of a company that is carried out to influence consumer behavior for the purpose of ongoing cooperation and product / brand purchases through direct communication, incentives, rewards, and so on. Loyaltybuilding tools (Linina, 2016). When describing the advantages and disadvantages of loyalty programs, it is necessary to distinguish between objectively inherent content and subjective implementation, which does not always meet the requirements. For example, scientific publications in this area include descriptions of both positive and negative experiences (Kotler \& Keller, 2006, 196-197; Toedt, 2015; Butcher \& Stephan, 2002, etc.). In this case, it is a question of realizing the possibilities of subjective loyalty programs with objective shortcomings. To some extent, these shortcomings can be addressed through the use of CRM, which, on the one hand, incorporates the positive elements of a loyalty program, but, on the other hand, is the next step in building and managing a business relationship with consumers.

There are several explanations and definitions of CRM in the scientific literature. The author believes that this can be explained by two reasons. First, with the advent of new marketing tools and new technologies, the functions of CRM are also changing and new opportunities are emerging in the field of consumer research and relationship management. Secondly, the analysis of CRM development and use is performed from specialists in various fields employees of marketing and sales departments, computer analysts, lawyers, etc. - a point of view which undoubtedly affects the understanding of the system.

The authors analyzed information on CRM theory and practice from a marketing perspective (Evans, 2012; Kotler \& Keller, 2006, 196-197; Smith \& Zook, 2011, 61-86; Harvey, 2015). For example, P. Kotler and K. L. Keller consider CRM to be "the use of detailed information about each consumer and the management of each consumer's contact with the product / brand / company" (Kotler \& Keller, 2006, 196-197). PR Smith and Z. Zook emphasize that CRM is "a complex business operation that creates and maintains a database to help retain consumers through their needs, complaints, suggestions, and purchases" (Smith \& Zook, 2011, 61-86). . According to Harvey, CRM combines two systems: internal (consumer research process) and external (building relationships with consumers), which are interconnected with the aim of attracting and retaining consumers by offering a product / brand that meets their needs (Harvey, 2015). . The authors of the paper agree with the opinion that "CRM is not just a technology and therefore it is not possible to increase the quality of relations with consumers only with the help of a computer program. CRM is a part of a company's interaction strategy with consumers" (Kraus, 2002). I. Linina offers the following definition of CRM: Consumer Relationship Management (CRM) is a company's strategy to attract, differentiate, serve and retain consumers through understanding and meeting their needs, developing long- 
term cooperation based on creating and maintaining a consumer database (Linina, 2016).

The essence of CRM is already expressed in its name the company's management's orientation towards building sustainable relationships with consumers. As a result, the company can get more satisfied and stable consumers, which will bring the company more income. CRM provides not only buying / selling, but also pre-purchase and post-purchase process management. Another important difference is related to the creation and use of a marketing database (MDB) based on new information technologies.

In summarizing publications on CRM, company reports, and reports on CRM conferences (Kotler \& Keller, 2006, 196-197; Smith \& Zook, 2011, 61-86; Tapp, 2011), the authors highlight the following key principles of CRM in consumer marketing databases (MDB), differentiation of consumers according to two criteria: needs and benefits for the business, personalized communication with consumers to obtain information on their needs, complaints, suggestions, on the one hand, and influence their actions on the other attracting new customers and retaining existing ones through incentives for repeat purchases and dialogue to increase loyal customers, building and managing long-term customer relationships to promote brand image and company reputation, which in turn affects consumer loyalty, relationship with consumers formation and management to ensure the average cost per consumer u Reducing and increasing profits by increasing the level of loyalty and optimizing the pre-purchase, sale / purchase and post-purchase process simultaneously from the consumer and business point of view. Of course, it is important not only to create an MDB and fill it with information, but also to use it rationally, because the effectiveness of CRM depends on its use. The purpose of using MDB is to link consumer needs, products / brands, price, product / brand distribution channels and communication in one system.

The authors join those researchers who first associate CRM with the company's marketing and management (Krauss, 2002; Reil \& Gibass, 2000; De Pelsmacker, et.al. 2007, 397-407; Anderson, 2007, etc.), with five stages (see Figure 2).

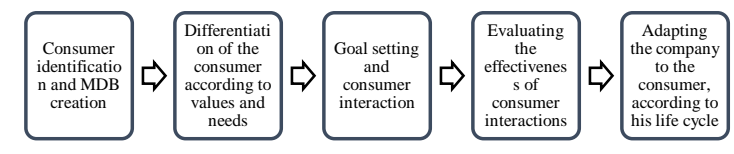

Fig. 2. Stages of consumer relationship management in the company (Linina, 2017).

In essence, the CRM scheme (see Figure 2) also meets the requirements of retail companies, of course, taking into account the specifics of the industry. Analyzing the publications on the use of CRM in retail (Anderson, et al., 2007; Griffin, 2002; Kim, et al., 2004), the authors have come to the conclusion that when developing a CRM system in retail, the following features should be taken into account: long-term system operation, it is necessary to ensure close functional cooperation of the company's marketing and sales departments / services, MDB creation, maintenance and improvement must be based on the customer card, the planning, creation and distribution of which must be reasonable and purposeful point-of-sale provision, the introduction and maintenance of MDBs in retail requires more investment in hardware, computer communications, software, staff training and education than in other sectors, and it must be borne in mind that not all individual consumers want to buy products at a point of sale is loyal and agrees to provide extensive information about himself, $\mathrm{k}$ also allow the company to use other databases for its personal data.

Consumer Relationship Management (CRM) systems are followed by ECR (Efficient Consumer Response), which we can translate as "effective response to consumer needs". As a result of the analysis of publications in the field of ECR (Dyer \& Harbir, 1998, 660-679; Seifert, 2001; Hofstetter, 2006; Salmon, 1993; Teece, et al., 1997, 509-533, etc.), the author concluded that despite insignificant differences, all authors consider ECR to be "cooperation between trade and industry to meet consumer needs and to promote irrational cost avoidance in the producer-to-consumer supply chain".

ECR became popular in developed countries in the mid-1990s and was based on increasing competition in world markets, the rapid development of information technology, the emergence and development of international trade organizations, the need to optimize distribution channels and the growing consumer demand for valuable and high-quality products and high quality of service. Researchers have emphasized that it is mutual trust between all partners involved in the product delivery process that is a prerequisite for achieving positive ECR results (Dyer \& Harbir, 1998, 660-679). ECR is a longterm relationship with relevant investments in the product delivery process, which aims to manage and resolve any disagreements in time to achieve an overall positive outcome (Teece, et al., 1997, 509-533).

However, agreeing with the statements of these researchers about the characteristics of ECR, the author considers that it is unreasonable to plan and implement this relationship management system in practice separately and independently of the implementation of CRM in retail. In essence, ECR is a modernized and supplemented CRM, as it serves the same purpose of managing customer relationships to meet their product needs and increase loyalty. It is clear that close cooperation between the manufacturer and the trader is needed in this area. Improved product quality will not matter if the retailer is unable to provide high quality customer service (a function of the CRM system) and loyalty rates will decline as a result. Summarizing the obtained information, it can be concluded that the basis for building a customer relationship system in retail companies is the effective use of CRM and ECR systems. 
The development of the chain LP - CRM - ECR logically leads to Relationship marketing management (RMM) in companies (see Figure 1). A lot of research, publications and monographs have been devoted to this topic (Harvey, 2015; Krauss, 2002; Seifert, 2011). Analyzing the scientific literature in this field, it can be concluded that relationship marketing management is a process of creating, maintaining and developing cooperation with consumers and business partners in order to facilitate the long-term supply of consumers. It follows that this system requires all departments / services / employees of the company to work in the field of customer relationship management. If the implementation and maintenance of CRM and ECR can be done only by a separate structural unit of the company, then RMM is the strategic mission and vision of the whole company's activities. Relationships with consumers are formed on several levels - economic, social, technical, legal, thus ensuring consumer satisfaction and loyalty.

In order to describe the management of consumer relations in retail companies in Latvia, it is important to first describe the situation in this area of the economy. According to the data published by the Central Statistical Bureau, in the first month of 2021, compared to the corresponding period of the previous year, the total retail sales have decreased by $8.9 \%$. A sharp decline in retail sales was already expected in January, as the retail sector operated under tight constraints throughout January. Thus, practically all non-food stores were not allowed to operate in person and the population could buy only a limited range of goods - food and those non-food items that are attributable to basic necessities. The restrictions also did not affect trade at service stations. Consequently, the retail trade of non-food products showed a sharper decline, excluding automotive fuel, which decreased by $23.4 \%$ year-on-year in January. Among non-food products, the strongest decline in January was recorded in retail trade of clothing and footwear, which was $64 \%$ lower than a year ago. The strongest negative contribution to the total results of non-food trade was made by a $28.9 \%$ decline in retail sales of metal products, paints and glass. Sales also decreased in several other categories of non-food products, including retail sale of information and communication technology equipment (-9.2\% year-on-year), retail sale of cosmetics and toiletries (-27.9\%), retail sale of cultural goods and leisure goods ( 29.2\%) and others Meanwhile, sales growth continued in January in retail sale of household electrical goods $(+21.2 \%)$ and after a break of several months, growth was again recorded in retail sale via mail order houses and online stores (+ 11.9\%).

The latest data on consumer and business economic confidence compiled by the European Commission show that in February, Latvian retailers' sentiment deteriorated for the fourth month in a row, approaching the initial level of the Covid-19 pandemic, which was the lowest in ten years. The consumer sentiment indicator showed a slight improvement over the previous month in February, but is still well below the pre-pandemic average. Consumers' perception of higher purchases in the coming months has remained very low, driven not only by general uncertainty and caution, but also by government restrictions on the retail sector, which prevent the purchase of non-essential goods. At the same time, consumers' assessment of their household's financial situation, showing a significant deterioration in January, improved sharply in February, reaching an all-time high.

At the beginning of the year, household savings also continued to increase, as evidenced by both the results of consumer surveys on current and planned savings and the Bank of Latvia's data on deposits. In January of this year, compared to January 2020, household deposits attracted by Latvian commercial banks grew at an even faster pace than at the end of last year - by $14 \%$, reaching 8.45 billion euros, which was determined by the increase in household funds at the end of the day. They increased by $27 \%$ over the year, while fixed-term household deposits and deposits redeemable at notice decreased by $28 \%$ and $33 \%$, respectively. This indicates an increase in the funds available to the population, which will be directed to consumption at a time when, as the epidemiological situation in the country improves, restrictions will be significantly relaxed not only in the trade sector, but also in the provision of services.

Also in February, the restrictions related to the control of Covid-19 disease in the trade sector have remained relatively strict, taking into account that the statistics on the spread of the virus in Latvia are still alarming. Although grocery and hygiene stores were allowed to sell all goods and bookshops were opened to shoppers from 8 February this year, epidemiological safety rules were strengthened at the point of sale, and most non-food stores are still closed. Consequently, it is expected that in February the retail trade sector will also decrease (Ministry of Finance of Latvia).

In the framework of this study, in order to directly and indirectly find out the factors influencing the choice of buyers' place of sale and their assessment in the real situation, a traditional method was used - a survey was organized with the help of a questionnaire. Preparing to use this method involves six steps.

1. Determining the standardization and degree of openness of the questionnaire. Taking into account the purpose of the survey and the characteristics of the respondents, the authors of the paper chose a standardized open questionnaire. This means that all respondents were offered the same questions in the same order, which ensures an objective comparison of answers. The questions were selected with one answer variant according to the Likert scale in a 5-point system and other answer variants in the system.

2. Determining the survey method. (Arhipova \& Bāliņa, 2006). The authors of the paper chose the following option - the survey was created on the website "Google Forms". The questionnaire was sent to the respondents via e-mails using the personal contacts of the author of the work, the questionnaires filled in by 398 respondents were recognized as valid for the research. All residents of Latvia were taken as a general group. At the $95 \%$ confidence level and the $5 \%$ margin of error, the minimum sample size was calculated - 387 respondents. 
Environment. Technology. Resources. Rezekne, Latvia Proceedings of the $13^{\text {th }}$ International Scientific and Practical Conference. Volume 1, 155-161

3. Determining the acquisition of the necessary information. Decision-making on this issue is to some extent facilitated by the focus group pilot studies already carried out on the factors influencing the choice of trading venue. In the light of the pilot study, questions were prepared to assess the factors influencing buyers' choice of outlet and their assessment. At the same time, it is very important to make sure that the respondents have the necessary information to answer the questions raised.

4. Question wording. To avoid such problems, the authors followed the recommendations of experts (Payne, 1978, 158-176):

- $\quad$ use simple words and sentences;

- $\quad$ avoid ambiguous words and questions;

- $\quad$ avoid prompting questions;

- $\quad$ avoid hidden alternatives;

- $\quad$ make sure the issue is specific.

5. Sequence of questions. The sequence of questions is also an important step, as it affects the respondent's interest in answering questions accurately. In order to avoid such mistakes, the authors of the paper followed special recommendations: general questions were asked at the beginning, but specific questions were followed; relatively difficult questions were placed on the second side of the questionnaire; questions on one topic were completed before moving on to the next topic.

6. Determining the form of the answer. In order to be able to provide a quantitative assessment and perform an appropriate analysis in the case of one possible answer, the authors used a Likert scale with a 5 (five) score, where 1 is a low grade and 5 is very high. But in order to assess the respondents' true skills, the degree of student's competence for a particular statement was chosen.

7. Statistical methods of processing and analysis of consumer survey evaluations. Extensive statistical analysis is possible for the questions given in the points. Using the SPSS computer program, the authors calculated the following indicators:

- $\quad$ the arithmetic mean $(\mathrm{X} \overline{)}$;

- $\quad$ the arithmetic mean standard error;

- $\quad$ median $(\mathrm{Me})$;

- $\quad$ mode (Mo);

- $\quad$ amplitude of variation;

- $\quad$ standard deviation (Kristapsone, Kamerāde et al.. 2011: 199).

For questions with possible multiple choice answers, the percentage of answers in the total sum of answer options was calculated.

The responses were further processed and analyzed.

First, the issue of buyers' evaluation in the choice of a point of sale was addressed (see Table 1). In this question, buyers rated the factors that influence their choice for a particular point of sale on a 5-point scale, where 1 meant that this factor was insignificant and 5 - very important.
TABLE 1 EVALUATION OF FACTORS INFLUENCING BUYERS WHEN CHOOSING SPECIFIC OUTLETS

\begin{tabular}{|l|l|c|c|c|c|c|}
\hline \multicolumn{1}{|c|}{$\begin{array}{c}\text { Factors } \\
\text { influencing the } \\
\text { choice of point } \\
\text { of sale }\end{array}$} & Mean & $\begin{array}{c}\text { Stan- } \\
\text { dard } \\
\text { error } \\
\text { of } \\
\text { Mean }\end{array}$ & $\begin{array}{c}\text { Me- } \\
\text { dian }\end{array}$ & Mode & $\begin{array}{c}\text { Stan- } \\
\text { dard } \\
\text { devit- } \\
\text { ation }\end{array}$ & $\begin{array}{c}\text { Skew- } \\
\text { ness }\end{array}$ \\
\hline $\begin{array}{l}\text { Shop location, } \\
\text { convenient } \\
\text { parking, public } \\
\text { transport and } \\
\text { other amenities }\end{array}$ & 4.52 & 0.04 & 4 & 4 & 0.82 & 4.00 \\
\hline $\begin{array}{l}\text { Assortment of } \\
\text { goods }\end{array}$ & 4.15 & 0.05 & 5 & 5 & 1.07 & 4.00 \\
\hline Price level & 3.55 & 0.05 & 3 & 4 & 0.99 & 3.00 \\
\hline $\begin{array}{l}\text { Marketing } \\
\text { activities: } \\
\text { advertising, } \\
\text { promotions, etc. }\end{array}$ & 3.28 & 0.05 & 3 & 3 & 1.09 & 2.00 \\
\hline $\begin{array}{l}\text { Quality of } \\
\text { service }\end{array}$ & 3.99 & 0.05 & 4 & 4 & 0.96 & 2.00 \\
\hline $\begin{array}{l}\text { Socially } \\
\text { responsible } \\
\text { action in the } \\
\text { Covid 19 } \\
\text { pandemic }\end{array}$ & 4.71 & 0.05 & 5 & 5 & 0.36 & 2.00 \\
\hline
\end{tabular}

Analyzing the obtained results on the factors influencing the choice of a particular point of sale for buyers, it can be seen that the buyers have chosen the socially responsible operation of the trading company in the conditions of the Covid 19 pandemic as the most important. The buyer's safety is a factor that ensures his satisfaction with a particular point of sale, and the small amount of variation indicates the unanimity of views on this issue. Other factors are listed in the following order of importance - store location, convenient parking, public transport and other amenities, product range, price level, quality of service and finally marketing activities.

On the other hand, when it comes to assessing the real situation, the situation is different (see Table 2).

TABLE 2 BUYER RATING FOR THE POINT OF SALE

\begin{tabular}{|l|c|c|c|c|c|c|}
\hline \multicolumn{1}{|c|}{$\begin{array}{c}\text { Point of sale } \\
\text { evaluation } \\
\text { factors }\end{array}$} & Mean & $\begin{array}{c}\text { Stan- } \\
\text { dard } \\
\text { error } \\
\text { of } \\
\text { Mean }\end{array}$ & $\begin{array}{c}\text { Medi- } \\
\text { an }\end{array}$ & Mode & $\begin{array}{c}\text { Stand } \\
\text { ard } \\
\text { devitat } \\
\text { ion }\end{array}$ & $\begin{array}{c}\text { Skew- } \\
\text { ness }\end{array}$ \\
\hline $\begin{array}{l}\text { Shop location, } \\
\text { convenient } \\
\text { parking, public } \\
\text { transport and } \\
\text { other amenities }\end{array}$ & 4.61 & 0.04 & 4 & 4 & 1.01 & 3 \\
\hline $\begin{array}{l}\text { Assortment of } \\
\text { goods }\end{array}$ & 3.88 & 0.05 & 3 & 3 & 0.98 & 3 \\
\hline Price level & 3.22 & 0.05 & 3 & 3 & 0.97 & 3 \\
\hline $\begin{array}{l}\text { Marketing } \\
\text { activities: } \\
\text { advertising, } \\
\text { promotions, etc. }\end{array}$ & 2.88 & 0.05 & 2 & 3 & 1.02 & 2 \\
\hline $\begin{array}{l}\text { Quality of } \\
\text { service }\end{array}$ & 4.08 & 0.05 & 4 & 4 & 0.96 & 4 \\
\hline $\begin{array}{l}\text { Socially } \\
\text { responsible } \\
\text { action in the } \\
\text { Covid 19 } \\
\text { pandemic }\end{array}$ & 3.41 & 0.05 & 2 & 3 & 0.98 & 3 \\
\hline
\end{tabular}


The location of the store, convenient parking, public transport and other amenities are rated the highest, then the quality of service, product range and only then socially responsible activities in the conditions of the Covid 19 pandemic, but marketing activities are rated the lowest.

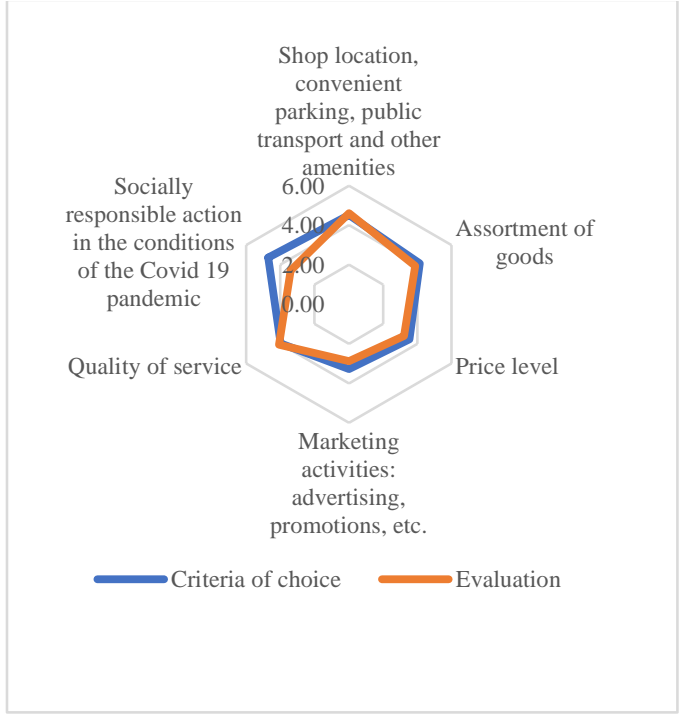

Fig. 3. Comparison of the arithmetic average of the factors influencing the choice of the buyer's point of sale with the arithmetic mean of the evaluation of the performance of the buyer's point of sale.

As shown in Figure 3, the location of the store, convenient parking, public transport and other amenities are rated on average 4.52 points, while the real rating is 4.61, which is even 0.09 points more. The assortment of goods by importance is on average 4.15 , but the real assessment is 0.27 points less and makes 3.88 average points. In this case, retailers should find out what does not satisfy consumers in their product range in the context of the Covid 19 pandemic and address this issue as a matter of urgency in order to increase customer satisfaction. Also, the price level in terms of importance is assessed with an average of 3.55, but in reality it is assessed with an average of 3.22 points, which is 0.33 points less. This issue should also be considered as a basis for the development of customer satisfaction. In turn, the quality of service is rated by 3.99 on average, but in reality it is rated by 0.09 points high - 4.08. Marketing activities are evaluated on average in reality with the lowest with 2.88, but in terms of importance with 3.28, where the largest difference is observed -0.40 . This difference could be explained by the fact that in a Covid 19 pandemic situation, buyers expect a more responsible approach to providing a variety of information to buyers and retailers need to take this into account. The biggest difference is observed in the conditions of socially responsible activity in the conditions of the Covid 19 pandemic, with a difference of 1.3 points, because the average importance score of this factor was 4.71 in the respondents' assessment, but the assessment of the real situation is 3.41. Respondents' answers show that they do not really feel social responsibility on the part of retail companies, and this can be a problem in the long run for customer satisfaction and loyalty. It is crisis situations that point to weak links in companies' operations, which can reduce a company's competitiveness.

\section{CONCLUSIONS}

1. Customer satisfaction and the process of building loyalty is an important factor in the development and competitiveness of retail businesses. This means that in order to improve their performance in this area, companies need to focus on the opportunities offered by loyalty programs, CRM and ECR, based on the information collected and compiled in marketing databases and to guide the use of RMMs in the future.

2. Analyzing the obtained results on the factors influencing the buyers' choice of a particular point of sale, it can be seen that the buyers have chosen the socially responsible activity of the trading company in the conditions of the Covid 19 pandemic as the most important (4.71). The buyer's safety is a factor that ensures his satisfaction with a particular point of sale, and the small amount of variation indicates the unanimity of views on this issue. The buyer wants to shop in sales outlets that have a socially responsible approach to organizing their activities.

3. According to the respondents, the location of the store, convenient parking, available public transport and other amenities are rated on average by 4.52 , but in reality with 4.61. In reality, this indicator is rated higher than the importance by 0.09 points. Similarly, the quality of service was assessed by importance on average with 3.99, but in reality it was assessed by 0.09 points high -4.08

4. Buyers rated the assortment of goods in terms of importance with an average of 4.15 points, but in reality with 3.88 points. In reality, the assessment is less than 0.27 points, which indicates buyers' dissatisfaction with the range of available goods. In turn, the price level was rated on average with 3.55 points, but in reality with 3.22 points, where the difference between the arithmetic averages is 0.33 points. The biggest difference between the averages in the significance and real assessment is observed in the marketing activity 0.40 points (3.28 - 2.88). These indicators point to the need for retail companies to ensure customer satisfaction, to evaluate the available assortment and pricing policy more carefully, and to develop marketing activities in accordance with the current situation.

5. Retailers in the Covid 19 pandemic would be advised to conduct both customer monitoring and surveys to accurately identify current customer satisfaction factors. When creating a marketing complex, including marketing communication in these conditions, use the obtained data on customer satisfaction, which will promote the development of customer loyalty, which in turn will increase competitiveness.

\section{REFERENCES}

[1] Anderson, J. L., Jolly, L. D., Fairhurst, A. E. (2007). Customer relationship management in retailing: a content analysis of retail trade journals. Journal of Retailing and Consumer services, November, 14 (6), pp. 394-399. 
Environment. Technology. Resources. Rezekne, Latvia Proceedings of the $13^{\text {th }}$ International Scientific and Practical Conference. Volume 1, 155-161

[2] Arhipova, I., Bālina, S. (2006). Statistika ekonomikā un biznesā. Rīga: Datorzinību centrs.

[3] Butcher, S., Stephan, A. (2002). Customer Clubs on Loyality Programms. Abingdon, Oxsn, GBR: Gower Publishing Limited.

[4] Covid-19 ierobežojumi tirdzniecības jomā būtiski ietekmējuši nozares rezultātus janvārī, FM Preses relīze 26.02.2021. Iegūts 13.03.2021. https://lvportals.lv/dienaskartiba/325374-fm-covid19-ierobezojumi-tirdzniecibas-joma-butiski-ietekmejusi-nozaresrezultatus-janvari-2021

[5] De Pelsmacker, P., Genens, M., Van den Bergh, J. (2007). Marketing Communication, 3rd ed., Prentice Hall, pp. 397-407, ISBN: 9780273721383.

[6] Dyer, J. H., Harbir, S. (1998). The Relational View: Cooperative Strategy and Sources of interorganizational Competitive Advantage. Academy of management Review, 23 (4), pp. 660-679.

[7] Hofstetter, J. (2006). Accessing the contribution ot ECR. ECR journal, vol. 6 issue 1, pp. 20-29.

[8] Evans, M. (2012). Consumer Behavior. Hoboken, NJ: Willey.

[9] Griffin, G. (2002). Customer Loyality. How to Earn it How To Keep it. San Francisco: Jossey Bass.

[10] Harvey, L. (2015). How to provide customer intelligence. [Online] no http://paperzz.com [Accessed 03/08.2015].

[11] Kim, J. W., Chi, J., Qualls, W., Park, J. (2004). The impact of CRM on firm and relationship lever perfomance in distribution networks. Communication of the Association for informations Systems. Vol. 14, pp. 632-652.

[12] Kotler, P., Keller, K. L. (2006). Marketing management. Hoboken, NJ: Prentice Hall.
[13] Krauss, M. (2002). At many firms, technology obscures CRM. Marketing News, 2002, 18 March.

[14] Kristapsone, S., Kamerāde, D.u.c. (2011). Ievads pētniecībā: stratēgójas, dizaini, metode. Rīga: RaKa.

[15] Liniņa, I. (2017). Customer Relationship Formation and Management in Retal Trade Enterprises in the Baltics Countries. Integrated and Sustanaible Regional Development Marketing and Sustainable Comsumption Book Series: Economic Science for Rural Development, Issue: 4, pp. 300-306.

[16] O’Reilijs, D., Gibass, D. (2000). Darījumu attiecības ar pircējiem.. Rīga, Biznesa augstskola Turība.

[17] Payne, S. L. (1978). The Art of Asking Questions. Princeton, N.I., Princeton University Press, pp.158-176.

[18] Reisheld, F. (2003). The One Number You Need to grow. Horvard Business Review, 81(12), pp. 46-54.

[19] Seifert, D. (2001). Efficient Consumer Response. Hampp, Mering.

[20] Smith, P. R., Zook, Z. (2011). Marketing Communication. New York: Kogan Page, pp. 61-86.

[21] Teece, D. J., Gary, P., Amy, S. (1997). Dynamic Capabilities and Strategic Management. Strategic Management Journal, 18(7), pp. 509-533.

[22] Toedt, M. (2015). The contribution of customer relationship management to sales perfomance in the hotel business. Summary of Doctoral Thesis, University of Latvia, Rīga.

[23] “A 'layman's' explanation of Ultra Narrow Band technology,” Oct. 3, 2003. [Online]. Available: http://www.vmsk.org/Layman.pdf. [Accessed: Dec. 3, 2003].

[24] Thomson ISI, EndNote 7. [CD-ROM]. Berkeley, Ca.: ISI ResearchSoft, 2003. 